\title{
High-Speed and High-Sensitive Immunochemical Detection using Pillar Arrays
}

\author{
Chisato Yoshimura Member (Brother Industries, chisato.yoshimura@brother.co.jp) \\ Hideo Nakano Non-member (Nagoya University, hnakano@agr.nagoya-u.ac.jp)
}

Keywords : Immuno disc, channel, pillar, reaction time, concentration gradient, range of measurement

\section{Themes and Purposes}

Among immunological measuring methods, ELISA process, which is extremely sensitive, is widely used for diagnoses of hundreds of diseases. An antigen-antibody reaction by ELISA process is normally executed in a container and it takes several and over 10 hours to complete all reactions. This makes prompt diagnosis quite difficult. Also, sometimes repeated measuring with dilution or enrichment of samples has to be done to make up for a narrow range of measurability. We propose a new device named Immuno Disc to solve those problems. There have been already many reports about executing immunological measurement on a chip. Our new device has multiple pillars inside a channel, to which samples are loaded. Signals on the pillars are measured alongside the channel. The first purpose of our study was to confirm the basic reliability and repeatability of the biochemical reactions on the device. To prove this, we produced pillars inside the channel and verified the following three points: the required time for antigen-antibody reaction, the incline of detected density along the channel, and the measurable range.

\section{Verification and Results}

We used an anemic diagnosis kit for abnormal iron metabolism called" Transferrin, Human, ELISA Quantitation kit". Inside the thin channel, which was a reaction area, arrays of fine pillars were formed to increase the area/volume ratio by 34 times. Pillars were manufactured by UV lithography process with a negative tone, chemically amplified, and thick type photoresist.

2.1 Reaction Time We measured fluorescent luminance of the substrate in the channel of $2.0 \mathrm{~cm}$ long, under the "pose" duration conditions of 5 minutes, 10 minutes, 15 minutes, 30 minutes at the steps to absorb the primary antibody, antigen, the

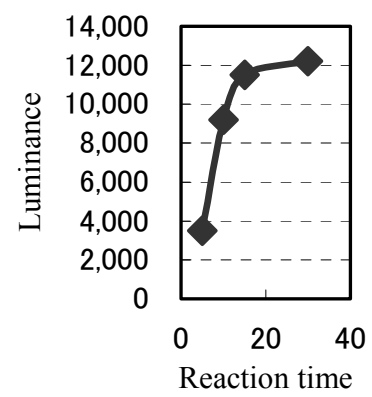

Fig. 1. Reaction time and luminance secondary antibody and the substrate. The results showed that the required pose duration for each absorption step was 10 to 15 minutes. The total measuring time required was tremendously reduced to less than one hour ( 15 minutes $\times 4$ steps), compared with the seven hours with the ordinary kit.

2.2 Density Inclination We also verified that a density inclination was formed along with the flow of samples because the reaction solution was flowing through the channel with pillar arrays. This brought us expectations: with a low concentration sample, more sensitive measurement would be available by arranging the proper amount of solution flow and waste flow system. With a sample of higher density, the measurable range would be widened by making the channel longer.

2.3 Measurable Range The integrated value was found by graphing the measured values of density inclination in the above 2-2. Fig. 2 shows the comparison with the values of luminance on an ordinary 96 -well plate.

It shows clearly that the measurable range of antigen concentration was widened to both higher and lower ones, which was almost 20 times wider than the former process. Thus we came to the conclusions: one was that the use of pillars made possible to improve the sensitivity, and the other was that its density inclination would be formed for arranging various measurement. Even density was measurable at one time by using the whole channel, which was impossible for the present ELISA process. At the same time, no special dilution or enrichment of samples was necessary. Our study showed the possibility to realize a highly sensitive and prompt diagnosis based on ELISA.

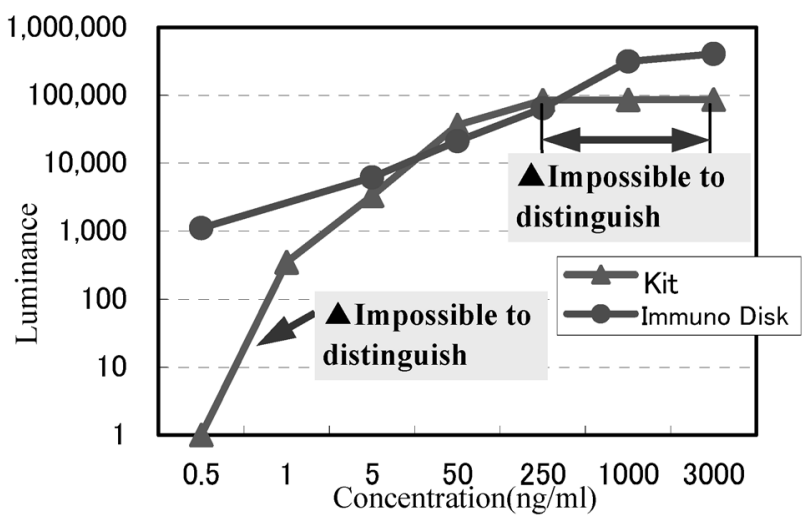

Fig. 2. Comparison of measurable ranges 


\title{
微細形状を利用した高速高感度免疫化学検出
}

\author{
正 員 吉村 千里* 非会員 中野 秀雄**
}

\author{
High-Speed and High-Sensitive Immunochemical Detection using Pillar Arrays \\ Chisato Yoshimura ${ }^{*}$, Member, Hideo Nakano**, Non-member
}

Enzyme-linked Immunosorbent Assay (ELISA) process is widely used for diagnosis, measurement of environmental materials, foods and so on, because of its extreme sensitivity for antigen-antibody reaction. This process, however, requires a long reaction time. We were able to shorten the reaction time required to less than 1 hour, which originally took several to more-than-ten hours, by widely enlarging the reaction area / volume with fabricating fine pillar arrays. Our process will show the possibility for instant diagnosis and instant medical treatment.

Moreover, ELISA process also requires dilution or enrichment of samples beforehand when the concentration of samples is unpredictable because the measurable concentration range is narrow. By changing the reaction area from a vessel to a channel, our device had a larger measurable area which made it possible to detect drastically a wider range of sample concentrations.

キーワード: イムノディスク, 流路, ピラー, 反応時間, 濃度勾配, 測定範囲

Keywords : Immuno disc, channel, pillar, reaction time, concentration gradient, range of measurement

\section{1. 序 論}

〈1·1〉免疫測定の概要 免疫測定とは, 被測定物質 (抗原) と, これに特異的に結合する検查試薬(抗体)との結合 を測定し，被測定物質の定性，及び，定量を行うものであ る。この抗原抗体反応を利用した免疫学的測定法は, 疾病 の診断, 環境関連物質の計測, 食品等, 広範な分野で汎用 的に利用されており, その回数や項目は増大の一途をたど っている(1) (3)。

中でも，酵素活性を指標として被測定物質を追跡し定量 する，酵素結合免疫吸着定量法(ELISA 法：Enzyme-Linked Immunosorbent Assay)は非常に鋭敏な感度を示し, 感染症や, 疾病の検査, 食物アレルギーや花粉症のスクリーニング等 の臨床検査に限っても, 数百種の項目で汎用的に利用され 威力を発揮している(4)。

ELISA のサンドイッチ法による検査方法は，96 個の窪み が形成されたプラスチック製のプレート(マイクロプレー 卜)を反応容器として用い, 検査の対象となる抗原と結合す る一次抗体を, 容器の内面に吸着させる。次に抗原を含む 試料を加えて, 抗原を一次抗体に結合させ，次いで二次抗

\footnotetext{
* ブラザー工業(株) 技術部

干467-0841 名古屋市瑞穂区苗代町 2-1

Engineering Dept., Brother Industries, Ltd.

2-1, Naeshiro-cho, Mizuho-ku, Nagoya 467-0841

** 名古屋大学 大学院生命農学研究科

干464-8601 名古屋市千種区不老町

Graduate School of Bioagricultural Sciences, Nagoya University

Furo-cho, Chikusa-ku, Nagoya 464-8601
}

体を加えて抗原に結合させ, 結合した二次抗体量を測定し, 抗原量を推定している。抗体の検出・定量には, 発光酵素 など光学的に標識した二次抗体を用いて酵素基質反応を起 こさせ, この際発生する酵素活性を, 吸光光度や蛍光光度 法で測定している。

ELISA 法での診断は高感度である反面, 検查に数時間を 要し, 検査を行う際のノウハウが必要とされている。加え て検出装置が大がかりな為, 大病院の検査室や外注の検査 センター内に使用が限られているといった制約がある。

また, ELISA 法より簡易的な方法として，イムノクロマ ト法(Immunochromatography)がある。この方法は，金コロイ ド標識した抗体と抗原の結合した複合体が, 試験紙上を移 動する途上に, 予めその抗原と結びつく抗体をライン状に 分布させ, 検出は色付きラインの有無で行う定性分析法で ある。この方法は, 早期に診断を下し, 適切な治療を開始 する必要がある感染症や疾病の迅速検査キット等に応用さ れている(5)。イムノクロマト法は簡便な診断が可能である 為, 小規模な医院にて多く用いられるが, 定量性に乏しい, 感度が良くない，サンプルの純度に測定結果が大きな影響 を受ける等の課題がある。

そこで, 本研究では, これら 2 つの測定法では両立し得 なかった, 高感度, 且つ迅速な測定, 熟練技術を必要とし ない簡便な操作性, コンパクト, 低コストな測定設備, 加 えて多検体, 数項目の同時測定が可能と考えられる反応デ バイスとして, 生化学と加工技術からアプローチし, Immuno Disc を試作し, 理論の検証を行った。 


\section{Immuno Disc の概要}

Immuno Disc の概要を図 1 に示す。試薬の送液を回転によ る遠心力で行い, 円盤形状の Immuno Disc 上面に形成され た放射状に広がる複数の流路の内部でイムノアッセイを行 うデバイスである。免疫学的測定のチップ上への構築につ いては，既に多数の試みがなされているが(6) (8), 流路内部 に多数のピラーを形成していること，流路全体をスキャン して測定を行うことが特徵として挙げられる。Disc の注入 口 A と慗がる流路に形成されているピラー部分の顕微鏡写 真を図 2 に, 流路内のピラーの電顕写真を図 3 に示す。

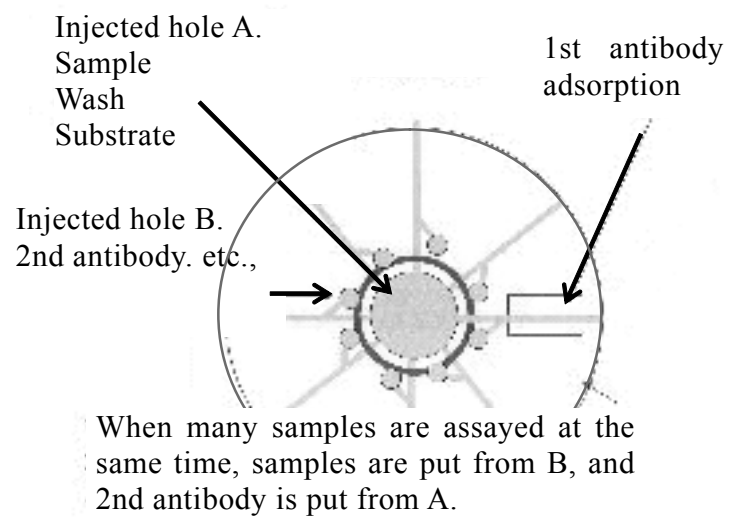

図 1 Immuno Disc $の$ 概要図

Fig. 1. Scheme of Immuno Disc.

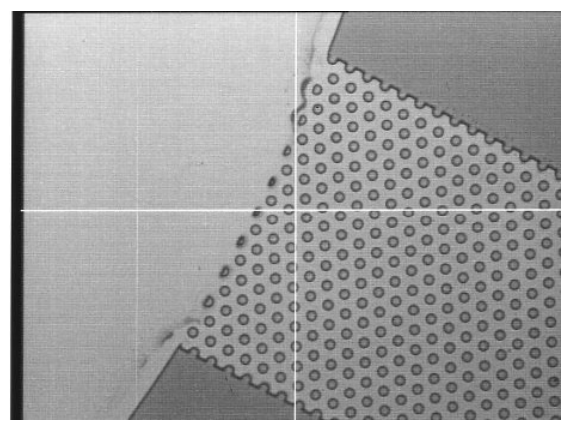

図 2 注入口と流路のピラーの写真

Fig. 2. Photograph of pillars of injection entrance and passage.

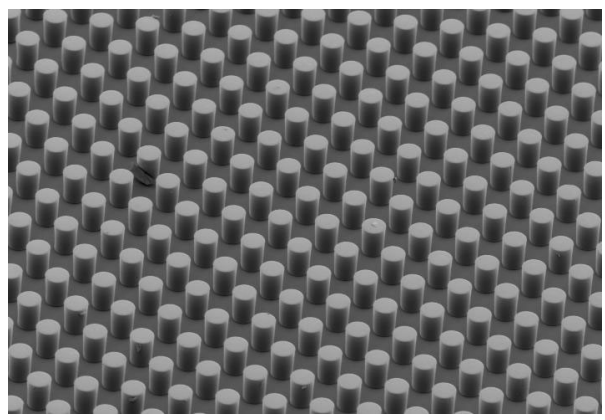

図 3 流路内のピラーの電顕写真

Fig. 3. SEM photograph of pillars on the passage.
今回評価した Disc は試作が容易な UV リソグラフィー法 を用いて, 4inch の Si ウェハ上に厚膜用化学増幅型 UV ネガ レジストで, 反応流路内に高さ $100 \mu \mathrm{m}$, 直径 $50 \mu \mathrm{m}$, ピッチ $100 \mu \mathrm{m}$, 図 2, 3 に示した様に千鳥配置でピラーを形成した パターンを形成後, ピラー及びウェハの表面に溶液の濡れ 性向上処理を施した。

尚, 今回は試作が容易な Disc の量産展開工法には, 数秒 〜数十秒で生産できる樹脂の射出成形法が適応されると考 え, 試作を試みた例を図 4 に示す。

Disc を回転させて生じる遠心力を利用することで多検体 同時に，且つ一様に送液を行うことが可能となる。例えば， 図 1 に示した円盤中央の注入口 A に共通の試薬を, 各流路 に設けられた注入口 B に個別の試薬を入れれば，多サンプ ルの同時アッセイや, 同一サンプルの複数アッセイを 1 度 に行うことが出来る。ポンプ等の送液装置やマイクロバル ブ等の送液を制御する機器が不要なので, 装置が簡易化で きる。

多サンプル(複数の抗原)の同時アッセイを行う場合は, 注 入口 A に一次抗体を入れて, 遠心力で複数の流路内に一度 に搬送し, 流路内の底面, 壁面, ピラーの表面に一次抗体 を吸着させ，次に，各々異なる抗原を流路毎に形成されて いる注入口 B から入れて送液することで, 流路毎に各々異 なる検査が出来る。二次抗体は注入口 A に入れて一度に全 ての流路に搬送すればよい。

また，同一サンプル(一種類の抗原)の複数アッセイは, 各々の注入口 B から異なる一次抗体入れて送液することで, 流路毎に各々異なる検査が出来る。次に, 抗原を注入口 A に入れ全ての流路一度に搬送し, 二次抗体は注入口 A に入 れて一度に全ての流路に搬送すればよい。

\section{3. 実験方法}

今回の検証では, まず, 理論的な生化学反応の基礎の確 認を再現性良く検証する事を目的として, 流路にピラーを 形成した際の, 抗原抗体反応の所要時間, 検出濃度勾配, 測定可能範囲の 3 項目について検証した。この際回転によ る送液は用いなかった。理由は遠心力で流路内を試薬が均 一に搬送出来ていないと, 反応のばらつきが生じる為であ る。

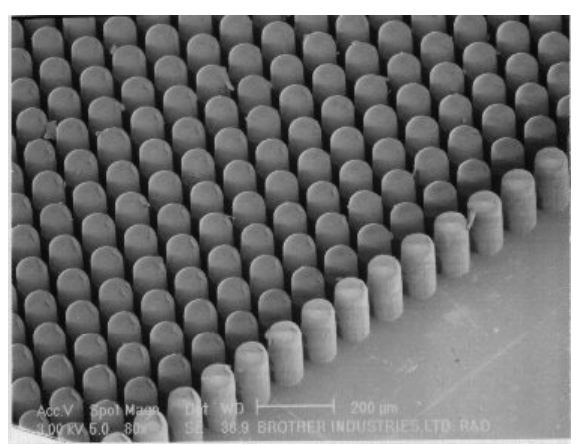

図 4 射出成形で作製した樹脂ピラーの写真

Fig. 4. Photograph of pillars made by injection molding. 
〈3.1〉 実験手順 ELISA 法での診断の 1 つに, 鉄代 謝異常による貧血の診断法があり, 血清トランスフェリン 受容体を, 可溶性受容体に対するモノクロナール抗体を用 いて測定するもので，正常範囲は 3.0 $8.5 \mu \mathrm{g} / \mathrm{mL}$ である。今 回の実験は，この市販キット Transferrin, Human, ELISA Quantitation キットを用いた。図 5 にキットの実験手順を示 す。Discでの実験では，上面に Discの注入，排出口に対応 する場所に貫通穴を設けた, 円盤状のシリコンゴム性カバ 一を注型で試作し，Disc と密着させた。試薬はピペットマ ンを用いて, 当初, ゴムカバーの中央注入口から流し込み, 外周側からピペットマンにて吸引を行ったが, 円周方向側 の排出口から流し込んだ方が各々の流路での実験が独立し て行えるので, 円周側から流し込み, 中央口から排出を行 つた。

〈3·2〉 反応基質の選定 Si 製 Disc は光が透過しない ので, 反応基質は蛍光基質である Amplex ${ }^{\circledR}$ Red Reagent (10-acetyl-3,7-dihydroxyphenoxazine)を用いた。図6にその反 応を示す。

この基質は HRP の存在下で過酸化水素と 1:1 で反応し, 非常に蛍光の強い Resorufin となる。Resorufin は化学的に安

$\begin{array}{lr}\text { 1st antibody adsorption } & 37^{\circ} \mathrm{C} 2 \mathrm{hr} \\ \text { Wash 2times } & \text { or } 4{ }^{\circ} \mathrm{C} \text { over night } \\ 37^{\circ} \mathrm{C} 2 \mathrm{hr}\end{array}$

図 5 Transferrin, Human, ELISA Quantitation キットでの実 験手順

Fig. 5. Protocol in a kit of Transferrin, Human, ELISA Quantitation.

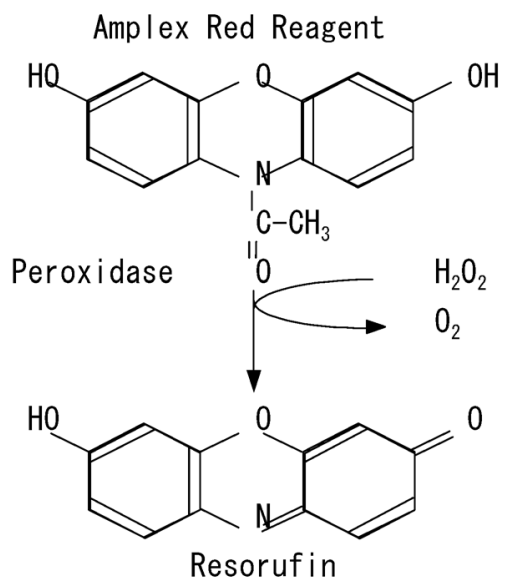

図 6 Amplex Red Reagent $の$ 反応式

Fig. 6. Equation of Amplex Red Reagent.
定で, 励起波長 $563 \mathrm{~nm}$, 蛍光波長 $587 \mathrm{~nm}$ という長波長のス ペクトルを持つものである。

〈3.3〉 流路内の反応面積 以下の評価は, $\phi 50 \mu \mathrm{m} の$ ピラーが形成された幅 $2 \mathrm{~mm}$, 長さは $2.0 \mathrm{~cm}$ 及び, $3.5 \mathrm{~cm}$ の 2 種類について述べる。この流路の面積/容量比を計算したと ころ, $320 \mathrm{~cm}^{2} / \mathrm{cm}^{3}$ であった。面積/容量比とは容量 $(\mathrm{ml})$ あた りの吸着分子数, 及び, 吸着に必要な拡散による移動距離 の目安となるもので, この值が高いほどより多くの分子が 固体の表面に吸着すると共に, 吸着に要する時間も短くな ると考えられる。

通常, ELISA のマイクロプレートでは $100 \mu 1$ の溶液を加え た状態で $9.4 \mathrm{~cm}^{2} / \mathrm{cm}^{3}$ であるので Disc 流路の面積/容量比は約 34 倍に相当することとなり, この值から, 最初に吸着させ る一次抗体の濃度を決定した。単位面積 $\left(\mathrm{cm}^{2}\right)$ あたり $250 \mathrm{ng}$ の蛋白質が吸着可能であると仮定すると, 飽和吸着させる ために必要な濃度 $\mathrm{S}$ は, 面積/容積比を $\mathrm{R}$ とすると,

$$
\mathrm{S}=0.25 \times \mathrm{R}(\mu \mathrm{g} / \mathrm{ml})
$$

と表される。この計算式より, 飽和吸着に必要な濃度 $\mathrm{S}$ は, 今回の流路において, $80 \mu \mathrm{g} / \mathrm{ml}$ となった。よって, 一次抗体 の濃度はこれよりやや高い值の $100 \mu \mathrm{g} / \mathrm{ml}$ とした。

\section{4. 検討と検証}

流路にピラーを形成した際の, 抗原抗体反応の所要時間, 検出濃度勾配, 測定可能範囲の 3 点について検討を行った。

$\langle 4 \cdot 1 \cdot 1\rangle$ 反応時間の検討 Disc の流路内に多数のピ ラーを形成することで, 反応表面積が増大寸る。面積/容量 比の值が上昇すると, 反応に要する時間が短縮され, 且つ, 吸着分子数の増加に伴う感度の上昇が期待できる。実験は, 流路長 $2.0 \mathrm{~cm}$ で, 一次抗体, 抗原, 二次抗体, 基質の各吸 着ステップで静置する時間を 5 分, 10 分, 15 分, 30 分と変 化させて，基質の蛍光輝度を測定した。

$\langle 4 \cdot 1 \cdot 2\rangle$ 反応時間の検証 反応時間について検証し た結果を図 7 に示した。静置時間 5 分と 10 分とでは 2 倍以 上異なるが, 15 分と 30 分とではほぼ一定となっている。こ の結果から, 各吸着ステップに必要な静置時間は 10-15 分

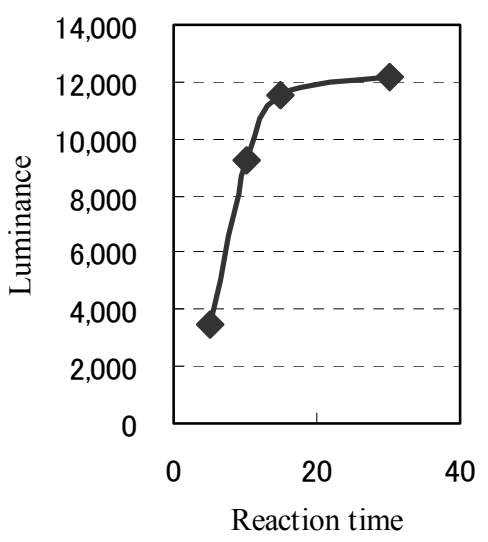

図 7 反応時間と輝度

Fig. 7. Reaction time and luminance. 


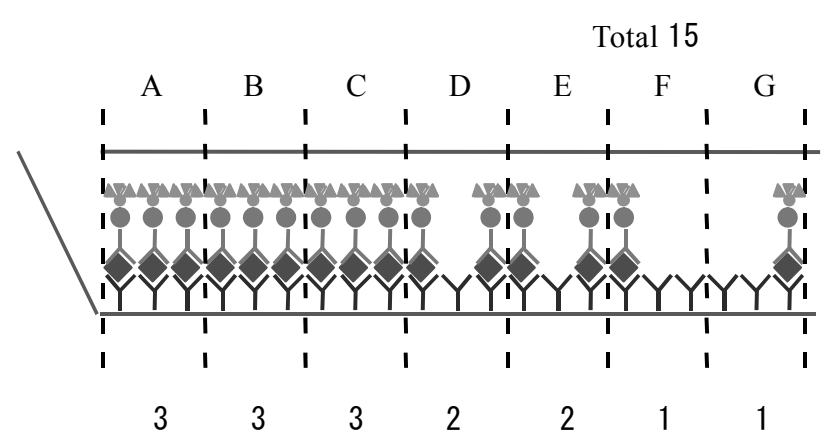

図 8 高濃度サンプルでの反応の模式図

Fig. 8. Pattern diagrams of reaction with a high- density sample.

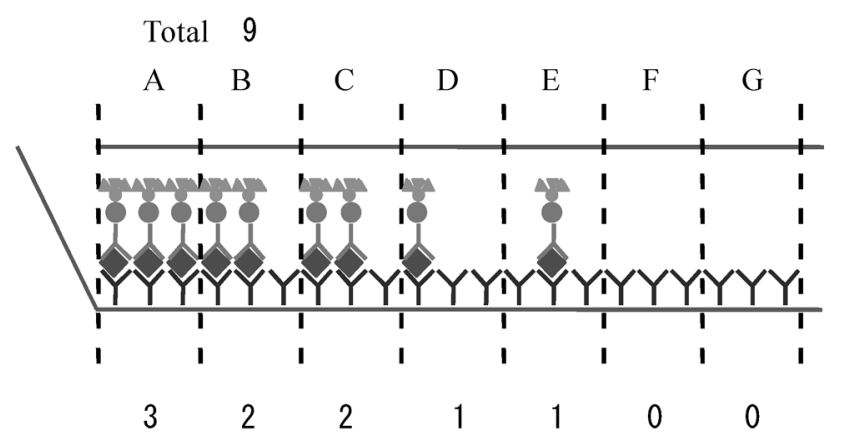

図 9 低濃度サンプルでの反応の模式図

Fig. 9. Pattern diagrams of reaction with a low- density sample.

であることが分かった。通常のイムノアッセイでは吸着を 4 ステップ行うため, 今回の流路を用いた場合の全体の測定 時間は 1 時間弱となる。

$\langle 4 \cdot 2 \cdot 1\rangle$ 濃度勾配の検討 流路内の吸着の濃度勾配 について，サンプルが高濃度の場合を図 8 に，低濃度の場 合を図 9 に示す。図内の記号は，流路底面から上方に向か って, 一次抗体, 抗原, 二次抗体, 基質の順に表している。

上方に左側が液の注入口で, 液は右側に流れて行くので あるが，高濃度のサンプルを流すと図 8 に示した様に，流 路の始めの方では抗原が一次抗体に対し過剩に存在してい る為, 吸着が飽和してしまう。高濃度になるほど吸着が飽 和する流路の距離が長くなる。そして，下流側に行くにつ れ抗原の濃度が低くなり, 次第に飽和吸着しなくなってい く。この結果, 吸着の濃度勾配が生じると推測される。

同様の現象は図 9 に示した低濃度の場合でも起きるが, 低濃度であると飽和吸着する流路の距離が短いので, より 早い段階で吸着量の勾配が生じると推測される。

この吸着した状態で, 二次抗体, 基質を反応させ一定距 離ごとに測定をすることにより, 濃度勾配を検出できると 考える。また, 測定值をグラフ化して積算值を求めること でより幅広い濃度のサンプルを測定することも可能と考え られ，その結果，測定範囲が大幅に広がり，従来の ELISA の測定法では判断出来なかった濃度差まで流路全体で判断 出来れば, 事前にサンプル濃度を推測して希釈等を行うこ

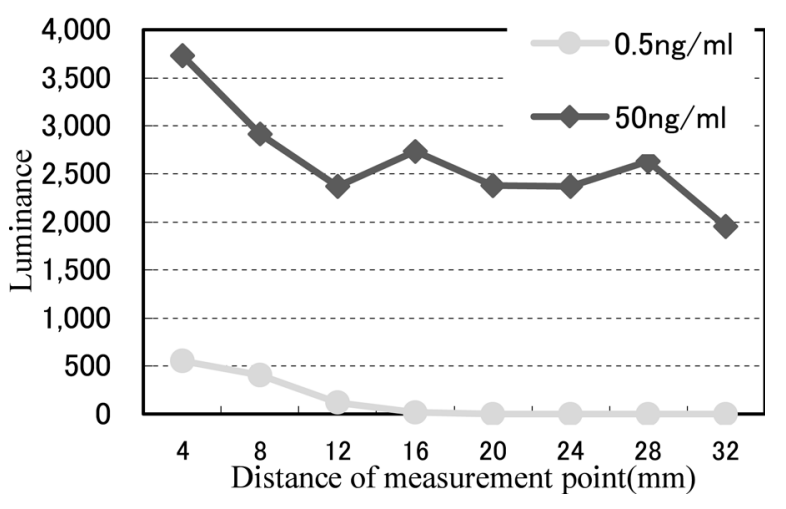

図 10 低濃度サンプルでの蛍光検出

Fig. 10. Fluorescence detection of a low-density sample.

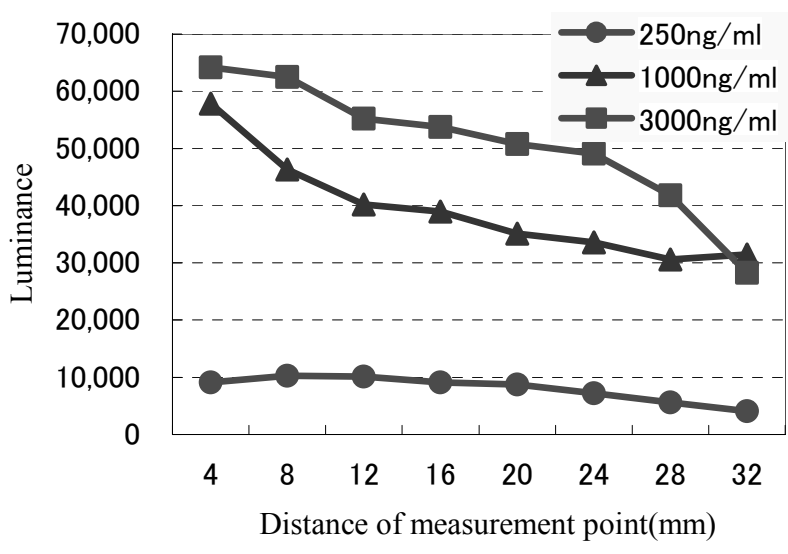

図 11 高濃度サンプルでの蛍光検出

Fig. 11. Fluorescence detection of a high-density sample.

となく測定が可能となり，より迅速な測定に繋がると期待 できる。

実際に吸着の濃度勾配が検出できるかどうかについて は, $3.5 \mathrm{~cm}$ の流路を用いて実験を行った。実験では Transferrin 濃度 $0.5 \mathrm{ng} / \mathrm{ml}, 50.0 \mathrm{ng} / \mathrm{ml}, 250 \mathrm{ng} / \mathrm{ml}, 1000 \mathrm{ng} / \mathrm{ml}, 3000 \mathrm{ng} / \mathrm{ml}$ の計 5 種類のサンプルを用い, 反応時間は $\langle 4 \cdot 1 \cdot 2\rangle$ 反応時 間の検証結果から, 各ステップ 15 分で行った。測定は $4 \mathrm{~mm}$ 毎に, 計 8 点で行った。

$\langle 4 \cdot 2 \cdot 2\rangle$ 濃度勾配の検証 流路に流した 5 種類の濃 度サンプルの内, $0.5 \mathrm{ng} / \mathrm{ml}, 50.0 \mathrm{ng} / \mathrm{ml} の 2$ 種類の蛍光検出結 果について図 10 に示した。残りの $250 \mathrm{ng} / \mathrm{ml}, 1000 \mathrm{ng} / \mathrm{ml}$, $3000 \mathrm{ng} / \mathrm{ml}$ の 3 種類の結果ついては, 図 11 に示した。何れ の濃度においても, 低濃度, 高濃度サンプル共に濃度勾配 が見られ，推測通りに検出できる事が確認された。

$\langle 4 \cdot 3 \cdot 1\rangle$ 測定可能範囲の検討 測定で得られた值を 利用し, 今回の流路での測定範囲を ELISA 法と比較した。 ELISA はキットの手順に従って行った。

また, 流路での測定範囲を求めるにあたって, その濃度 勾配を利用するために 8 点での測定值の合計を用いること とした。

$\langle 4 \cdot 3 \cdot 2\rangle$ 測定可能範囲の検証 市販キットと今回試 
表 1 測定可能範囲の比較

Table 1. Comparison of measurable ranges.

\begin{tabular}{|c|r|r|}
\hline \multirow{2}{*}{$\begin{array}{c}\text { Concentration of } \\
\text { Transferrin }\end{array}$} & \multicolumn{2}{|c|}{ Luminance of fluorescence } \\
\cline { 2 - 3 } & Kit on the market & Immuno Disk \\
\hline $0.5 \mathrm{ng} / \mathrm{ml}$ & 0 & 1,101 \\
\hline $1 \mathrm{ng} / \mathrm{ml}$ & 347 & - \\
\hline $5 \mathrm{ng} / \mathrm{ml}$ & 3,287 & 6,127 \\
\hline $50 \mathrm{ng} / \mathrm{ml}$ & 36,294 & 21,084 \\
\hline $250 \mathrm{ng} / \mathrm{ml}$ & 83,821 & 64,376 \\
\hline $1,000 \mathrm{ng} / \mathrm{ml}$ & 85,522 & 314,067 \\
\hline $3,000 \mathrm{ng} / \mathrm{ml}$ & 85,980 & 405,582 \\
\hline
\end{tabular}

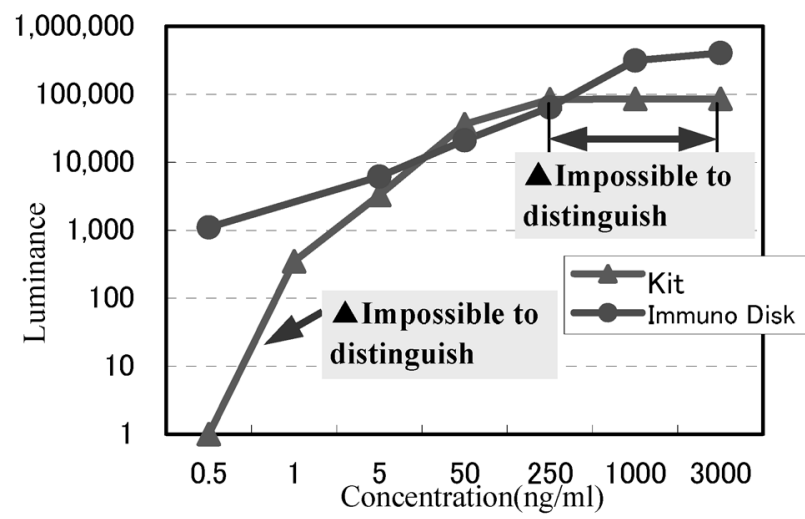

図 12 測定可能範囲の比較

Fig. 12. Comparison of measurable ranges.

作した Immuno Disc での測定可能な範囲を検証した結果を 表 1 に示した。Disc での值は，流路全体の合計值である。 表 1 での值を対数グラフにしたものを図 12 に示した。

市販キットでは, $0.5 \mathrm{ng} / \mathrm{ml}$ の濃度では輝度が低すぎて検出 が出来ず，また $250 ， 1,000$ 及び $3,000 \mathrm{ng} / \mathrm{ml}$ の輝度の差が殆 ど無く $250 \mathrm{ng} / \mathrm{ml}$ 以上の濃度になると判別が出来なかったの に対し, Disc では, $0.5 \mathrm{ng} / \mathrm{ml}$ での濃度が出来， 250，1,000, $3,000 \mathrm{ng} / \mathrm{ml}$ の輝度の差は明確に現れ判別が可能であった。言 い換えれば，ELISA の測定範囲は 1.0-250ng/ml であるのに 対し, 今回の流路では $0.5-3,000 \mathrm{ng} / \mathrm{ml}$ と約 20 倍広い濃度範 囲で測定が出来た。

\section{5. 考 察}

〈5·1〉反応時間について 通常 ELISA 法の測定では 7 時間〜10 数時間要し, 即時診断, 即時治療は難しかった が，今回の Disc を使った方法では，多くとも 1 時間弱で免 疫測定が完了出来たことから大幅な時間の短縮が可能とな ることが実証された。この短縮は, 同一容積に対し反応面 積が増したことに由来すると考える。

しかし, Disc はキットに比べ, 面積/容量比が 34 倍増えた のに対し, 反応時間は約 7 倍程度に促進されたに過ぎない。 大幅な時間短縮がなされなかった理由として, 最初に吸着 させる一次抗体の濃度を決定する際, 仮定した単位面積あ
たりに吸着する蛋白質量の值が，実際に吸着可能な量より も低く仮定してしまい，そして，それにより一次抗体の濃 度が飽和吸着に必要な濃度より低く設定されてしまったこ とが考えられる。即ち, 一次抗体が飽和吸着していなけれ ば，抗原を吸着する効率が下がり，抗原-抗体反応が飽和す るために必要な時間が長くなってしまったことが推測され る。

また, 考えられ得るもう一つの要因として, 液の置換が 適正に行われていなかった可能性が挙げられる。今回の実 験では, シリンジで吸引するという方法で送液, 廃液を行 った為, 液を完全に置換できているか否かについては確認 が難しく, 直ちに置換出来ていない箇所については, 次の ステップの試薬が送液後, 直ちに反応表面に接すること が出来ず, その結果, 予想より長い反応時間が必要になっ てしまった事も推測される。

今後の課題としてこれらの考えられる要因について検討 する為に, より高濃度の一次抗体を最初の吸着に用いて反 応時間の検討を行う, 液の置換が確実に行える装置, 方法 の開発が必要と考える。

〈5·2〉測定可能範囲について 通常の ELISA 法では 測定濃度領域が狭い為, 濃度の予測が付かない場合, サン プルの希釈や濃縮工程を要し, 複数の測定を行わざるを得 なかったが，Disc は高濃度側，低濃度側ともに測定範囲が 広がっていることから，ピラーの効果による感度の上昇及 び, 濃度勾配を利用した測定法の効果が確認出来たと考え る。低濃度サンプルにおいては, より適正な送液及び廃液 の方法を用いれば，更に感度が上昇すると考えられる。一 方，高濃度側では流路をより長いものを用いることにより 測定範囲は更に拡大寸ると考えられる。

また, 濃度勾配によって得られる検出值をより正確に利 用する方法については試薬, デザイン等多方面からの適切 なアプローチを考案すれば，より精度の高い測定が可能と 考える。

マイクロ化は感度の低下を招くが，ピラーを立てて表面 積を増大させることで実質的な検出感度が微量測定にも関 わらず上がる事が特徵であり, 臨床検査に利用できる可能 性を示すことが出来た。

\section{6. まとめ}

免疫学的測定法のなかでも非常に鋭敏な感度を示し汎用 的に利用されている ELISA 法による抗原抗体反応は, 通常 容器内で反応が行われるが, 反応エリアを微細な流路に置 き換え, 更に流路内に微細なピラーアレイを形成して反応 エリアの面積/容積比を大幅に増大させたところ, 反応に掛 かる所要時間を大幅に短縮出来た。ピラーは厚膜用化学増 幅型UVネガレジストを用いたUVリソグラフィーによって 作製した。

また，ピラーアレイを形成した流路に反応溶液を流すこ とで, 流路の流動方向に反応の濃度勾配が形成されたこと を確認した。その測定值をグラフ化して積算值を求めると, 
測定可能な抗原の濃度領域が従来よりも高濃度側, 低濃度 側とも，合わせて約 20 倍と大幅に広がったことから，ピラ 一の効果による感度の上昇及び，濃度勾配を利用した測定 法の効果が確認出来た。低濃度サンプルにおいては, より 適正な送液及び廃液の方法を用いることで更に感度の上昇 が期待され, 高濃度側では流路をより長いものを用いるこ とで更に測定範囲を拡大することが可能と考えられ，現行 の ELISA の測定法では判断出来なかった濃度差まで流路全 体を使うことで, サンプル濃度の調整希釈, 濃縮等を行う ことなく一度に判断出来, 高感度, 即時診断, 即時治療 の可能性を示した。

(平成 18 年 3 月 27 日受付)

\section{文献}

(1) J. Clausen : "Immunochemical Techniques for the Identification and Estimation of Macromolecules", 3rd ed, Elsevier/North-Holland Biomedical Press (1989)

( 2 ) D. M. Weir, L. A. Herzenberg, C. Blackwell, and L. A. Herzenberg : "Immunochemistry", 4th ed, Blackwell Scientific Pub. (1986)

(3) 滝上英孝・酒井伸一：「ダイオキシン類, PCB を検出するバイオア ッセイ」, ぶんせき, Vol.9, pp.502-510 (2003)

（4）山本重夫，他：バイオ検査薬の開発，シーエムシー出版 (2000)

(5) M. Hara, S. Takao, S. Fukuda, Y. Shimazu, M. Kuwayama, and K. Miyazaki : "Comparison of Four Rapid Diagnostic Kits Using Immunochromatography to Detect Influenza B Viruses", J. of Infection and Chemotherapy, Vol.79, No.10, pp.803-811 (2005-10) (in Japanese) 原三千丸・高尾信一・福田伸治・島津幸枝・桑山 勝 - 宮崎佳都夫 : 「B型インフルエンザに対する4種類のイムノクロマト法迅速診断キ ットの比較検討」, 日本感染症学誌, 79, 10, pp.803-811 (2005-10)
(6) M. J. Madou, L. J. Lee, S. Daunert, S. Lai, and C. H. Shih : "Design and Fabrication of CD-Like Microfluidic Platforms for Diagnostics: Microfluidic Functions", Biomedical Microdevices, Vol.3, No.3, pp. 245-254 (2001-3)

( 7 ) M. J. Madou, Y. Lu, S. Lai, C. G. Koh, Y. J. Juang, L. J. Lee, and B. Wenner : "A Novel Design on a CD Disk for 2-Point Calibration Measurement", Sensors and Actuators A, Vol.91, No.3, pp.301-306 (2001-3)

(8) J. F. Michael : "CD Simplicity”, Modern Drug Discovery 35, pp.35-39 (2003-11)

吉 村 千 里 (正員) 名古屋工業大学工学部高分子工学科

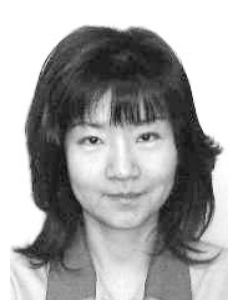
卒業，ブラザー工業(株)入社。技術部所属。入 社以来, 超精密射出成形技術開発に従事。LIGA プロセスの研究開発の他, 次世代の製造技術開 発に要求されるマイクロ, ナノオーダーの超精 密構造体の創製技術開発と, そのアプリケーシ ヨン展開に従事。

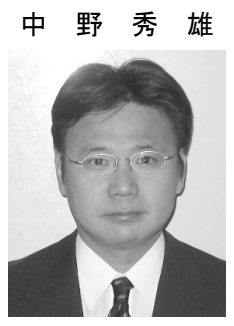

（非会員） 1985 年東京大学化学工学科卒業。 1991 年東京大学工学系研究科化学工学専攻, 博 士課程単位取得後退学。1991 年名古屋大学農学 部助手。1995 年同助教授。2005 年名古屋大学 大学院生命農学研究科教授。生物工学会, 農芸 化学会, 化学工学会等会員。主な研究テーマは, 無細胞蛋白質合成系, 蛋白質工学, 抗体工学な ど。 